\title{
中國科学院学部成立，大会阙於建議依法 嚴懲胡風反革命集团的决議
}

\section{5 年 6 月 10 日中國科攀院学部成立大會全體會誐通過}

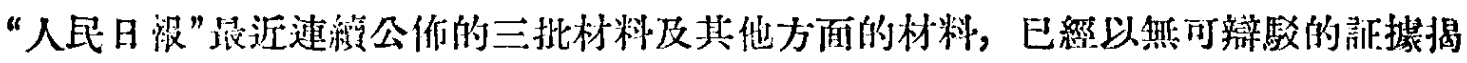

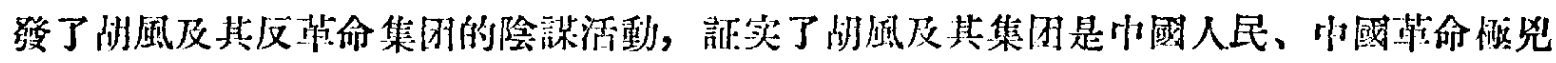

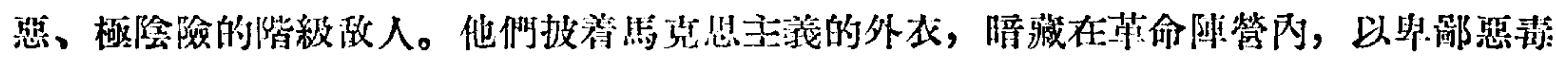

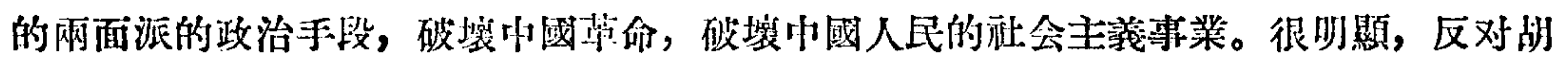

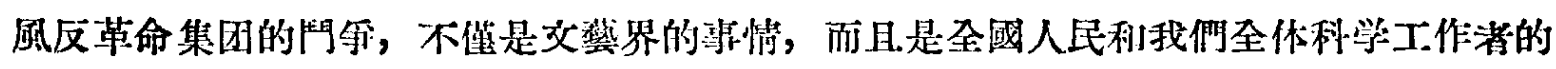

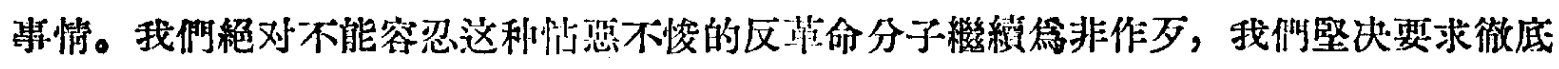

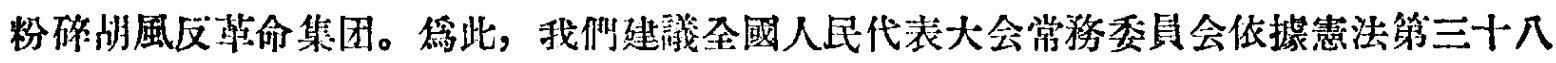

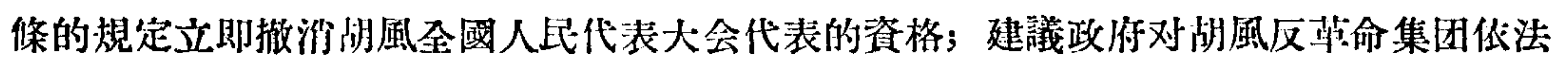
擘嶪。

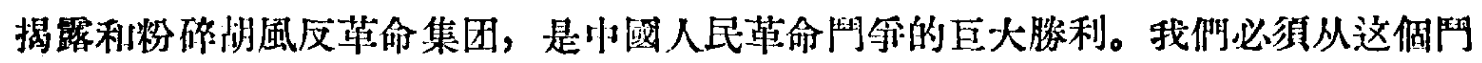

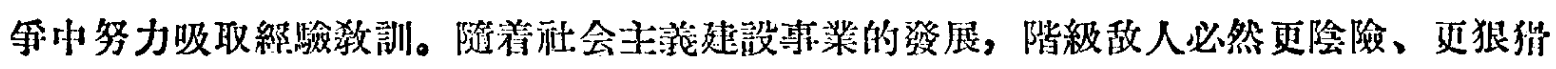
地以兩面派的手法進行反革命活動。因此，我們号召全体科学工作孝必須百倍地提酷政

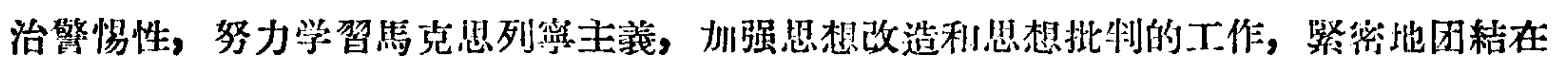

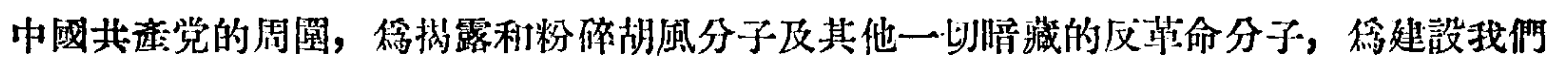
社会主義的偉大祖國耐堅决班爭。 